\title{
LEKTIN DARI SPONS Cliona varians ASAL PERAIRAN MALALAYANG MANADO
}

\section{(Lectin of Sponge Cliona varians from Malalayang Water Manado)}

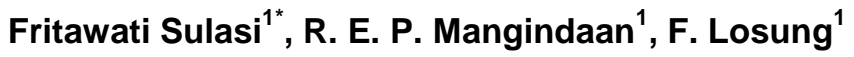 \\ ${ }^{1}$ Program Studi IImu Kelautan, Fakultas Perikanan dan IImu Kelautan, Universitas Sam \\ Ratulangi, Manado \\ e-mail : sulatimbuleng@yahoo.com
}

Lectin is found in various organisms including marine organisms such as marine sponges. Lectin of sponge Cliona varians from Brazilian water was investigated. However, lectin activity of sponge $C$. varians from Manado water was not investigated yet. The purpose of the research is to determine lectin activity of $C$. varians and the carbohydrate-binding site. Extraction using metode by Moura et al. (2006). Sponge centrifugated using tris $\mathrm{HCl}$ then purified with acetone until the lectin extract obtained. The result show that sponge $C$. varians in Manado water have the lectin activity up to $3750 \mathrm{ppm}$. However, the carbohydrate-binding site was not determined yet.

Keywords : lectin, sponge, Cliona varians

Lektin telah ditemukan di berbagai organisme termasuk organisme laut seperti spons. Spons Cliona varians dari perairan Brazil memiliki aktivitas lektin. Namun belum diteliti aktivitas lektin dari spons $C$. varians dari perairan Manado. Penelitian ini bertujuan untuk menentukan aktivitas lektin dari spons $C$. varians dan menentukan sisi pengikat gula. Ekstraksi menggunakan metode Moura dkk. (2006). Spons disentrifus menggunakan tris $\mathrm{HCl}$ setelah itu dimurnikan dengan aseton hingga diperoleh ekstrak lektin. Hasil pengujian menunjukkan bahwa spons C. varians pada perairan Manado memiliki aktivitas lektin hingga pada konsentrasi 3750 ppm. Namun sisi pengikat gula dari lektin tersebut belum bisa ditentukan.

Kata kunci : lektin, spons, Cliona varians

\section{PENDAHULUAN}

Organisme laut di perairan Manado telah menjadi objek penelitian oleh para ilmuwan baik di dalam negeri maupun di luar negeri. Avertebrata laut merupakan salah satu objek yang banyak di teliti sebagai sumber substansi bioaktif. Banyak substansi bioaktif yang telah diisolasi dari organisme-organisme perairan laut Manado, di antaranya merupakan senyawa baru. Salah satu dari organisme-organisme tersebut adalah spons.

Spons dianggap sebagai pabrik kimia di lingkungan laut karena memproduksi senyawa kimia beragam (Kim dan Dewapriya 2012). Salah satu jenis spons, Cliona varians, telah diteliti menghasilkan substansi bioaktif lektin yang dapat menghambat pertumbuhan sel leukimia (Queiroz dkk. 2009).

Menurut D'adamo (2007) lektin adalah protein non imun alami yang secara khusus berinteraksi dengan molekul gula tanpa memodifikasi gula tersebut. Namun definisi ini tidak berlaku lagi karena lektin-lektin I-type masuk dalam kelompok imunogloblulin, misalnya sialoadhesin (Hirabayashi 1997). Berdasarkan mekanisme kerjanya yang mirip antibodi, lektin 
dapat digunakan hampir di seluruh aspek biologi. Lektin dapat mengenali secara spesifik molekul/residu karbohidrat tertentu (Utama 1996). Aktivitas lektin dipengaruhi oleh suhu dan $\mathrm{pH}$. Aktivitasnya berkurang pada suhu di atas $60^{\circ} \mathrm{C}$. Dan pada $\mathrm{pH}$ 6-8 aktivitasnya bagus (Moura dkk. 2006).

Lektin tersebar di organisme hidup dan bereaksi dengan makromolekul glikosilasi (Gilboa-garber dan Garber 1989). Lektin telah diisolasi dari kacang (Wong dan Ng 2005), ikan (Watanabe dkk. 2008) tikus (Kasper dkk. 1993) dan pisang (Swanson dkk. 2010). Pada tanaman, lektin digunakan sebagai sistem pertahanan terhadap jamur dan serangga sedangkan pada mikroorganisme lektin berperan dalam menginfeksi mikroorganisme seperti virus dan bakteri yang masuk ke tubuh (Sharon dan Lis 2004). Pada organisme laut, lektin telah diisolasi dari organisme-organisme seperti alga laut Gracilaria verrucosa (Ngkuno 2010) dan Eucheuma gelatinae (Rawung 2006) serta spons Haliclona crater (Pajic dkk. 2002) dan Axinella corrugata (Dresch dkk. 2012).

\section{METODE PENELITIAN}

\section{Pengambilan Sampel Spons}

Sampel spons yang digunakan diperoleh dari perairan Malayang dengan menggunakan alat bantu selam. Sampel yang diperoleh dimasukkan dalam plastik sampel kemudian disimpan dalam termos yang berisi es. Setelah itu sampel dibawa ke laboratorium Kimia Bahan Hayati Laut Fakultas Perikanan dan IImu Kelautan Universitas Sam Ratulangi untuk diteliti.

\section{Ekstraksi Lektin}

Spons yang diperoleh dari perairan Malayang diekstrak menggunakan metode Moura $d k k$. yang telah dimodifikasi. Sampel spons yang diperoleh, dipotong kecil lalu ditimbang 500 gram dan dihaluskan menggunakan mixer. Setelah itu ditambahkan larutan tris $\mathrm{HCl}$ dengan perbandingan $2: 1$ dan dihomogenasi menggunakan pengaduk pada suhu $4^{\circ} \mathrm{C}$ selama 2 jam. Selanjutnya campuran disaring dan disentrifus pada kecepatan 3200 rpm selama 15 menit pada suhu ruangan. Supernatan yang diperoleh ditambah aseton dengan perbandingan $1: 1$, lalu di sentrifus dengan kecepatan 3200 rpm selama 15 menit pada suhu ruangan. Selanjutnya presipitat yang diperoleh di keringkan dalam freeze dryer dan ditimbang sehingga diperoleh ekstrak kasar lektin.

\section{Penentuan Aktivitas Lektin}

Ekstrak kasar lektin dilarutkan dalam salin dengan konsentrasi 6000 ppm, selanjutnya $100 \mu \mathrm{ll}$ salin dimasukkan ke dalam semua cekungan microtiter plate. Setelah itu ekstrak kasar lektin sebanyak $100 \quad \mu l$ ditambahkan pada cekungan nomor 1 , diaduk dengan mikropipet kemudian $100 \mu \mathrm{l}$ dari campuran dipindahkan ke cekungan ke-2 dan diaduk, demikian dilakukan seterusnya sampai cekungan ke-7 dan $100 \mu \mathrm{l}$ dari cekungan ke-7 dibuang, sehingga terbentuk suatu seri pengenceran 2 kali. Dalam cekungan ke-8 tidak ditambahi ekstrak lektin sehingga berlaku sebagai kontrol. Selanjutnya ke dalam tiap cekungan ditambahkan $100 \mu$ l suspensi eritrosit. Setelah pengadukan perlahan, keseluruhan plate ditutup dengan plastik tipis dan diinkubasi selama dua jam pada suhu ruangan. Selanjutnya 
dilakukan pengamatan secara makroskopis dan mikroskopis. Pengamatan makroskopis dilakukan dengan cara mengamati titer aglutinasi pada titik pengenceran tertinggi yang memberikan aglutinasi positif. Untuk pengamatan mikroskopis menggunakan mikroskop, dengan cara mengambil cuplikan pada cekungan di mikrotiter plate, diteteskan di kaca preparat lalu ditutup dengan kaca objek kemudian diamati di bawah mikroskop.

\section{Penentuan Sisi Pengikat Gula}

Jenis-jenis gula yang digunakan yaitu, $\mathrm{D}(-)$-Arabinose, $\mathrm{D}(+)$-Xylose, $\mathrm{D}(+)$-Glucose, $\mathrm{D}(+)$-Galactose, Manitol, L-Rhamnose, Inositol, D(+)-Mannose, $\mathrm{D}(+)$-Glucosamine, sodium glucuronat, $\mathrm{N}$-acetyl-D-glucosamine, Maltose, Lactose, Saccharose dan Raffinose. Polisakarida yang digunakan yaitu Arabic gum dan Starch potato. Setiap jenis gula dilarutkan dalam salin dengan konsentrasi $50 \mathrm{mM}$. Dengan multimikropipet, $50 \mu \mathrm{l}$ salin dimasukkan ke cekungan nomor 1 sampai 6 . Selanjutnya dengan mikropipet $50 \mu \mathrm{l}$ larutan gula $(50 \mathrm{mM})$ ditambahkan pada cekungan ke-1 dan diaduk. Sebanyak $50 \mu \mathrm{l}$ dari campuran tersebut dipindahkan pada cekungan ke-2 dan diaduk. Demikian seterusnya sampai pada cekungan ke-5, sehingga terbentuk suatu seri pengenceran dua kali dari larutan gula. Cekungan ke-6 tidak ditambahkan larutan gula sehingga berlaku sebagai kontrol. Pada tiap cekungan ditambahkan ekstrak lektin dengan konsentrasi titer tertinggi yang masih menunjukkan aktivitas aglutinasi.

Uji hambat gula ditentukan setelah inkubasi selama 2 jam pada suhu ruangan dan diuji terhadap eritrosit manusia. Pengamatan uji hambat gula dilakukan secara makroskopik dan mikroskopik. Tiap cekungan diisi suspensi eritrosit $(0,5 \%)$ sebanyak $50 \mu \mathrm{ll}$. Penentuan gula spesifik dari lektin ditentukan dengan uji hambat gula.

\section{HASIL DAN PEMBAHASAN}

\section{a. Ekstraksi Lektin dari Sponge $C$. varians}

Dari sampel $C$. varians sebanyak $500 \mathrm{gr}$, setelah diekstraksi diperoleh $10.25 \mathrm{gr}$ ekstrak basah, yaitu ekstrak yang masih tercampur dengan pelarut. Ekstrak ini kemudian dikeringkan dan diperoleh ekstrak sebanyak $0.47 \mathrm{gr}$.

\section{b. Uji Aktivitas Lektin}

Pengamatan dilakukan secara makroskopis dan mikroskopis. Hasil yang diperoleh pada pengamatan makroskopis dapat dilihat pada Gambar 2.

Pada hasil pengamatan nampak bahwa tidak ada perbedaan pada kedua ulangan dan aglutinasi terjadi pada cekungan 1 sampai 4 dengan konsentrasi lektin 3750 ppm. Sedangkan pada cekungan 5 sampai 24 tidak terjadi aglutinasi.

Pada pengamatan mikroskopis (Gambar 3) dengan konsentrasi 15.000 ppm nampak tidak terjadi ikatan antara lektin dan sel darah.

Pada pengamatan secara makroskopis nampak terjadi aglutinasi, sedangkan secara mikroskopis tidak terjadi demikian. Pada titer aglutinasi yang menunjukkan adanya aglutinasi diamati secara mikroskopis adalah seperti yang nampak pada Gambar 4. Hal ini dapat disebabkan terjadinya denaturasi lektin yang disebabkan oleh perubahan suhu dan mekanik, dalam hal ini guncangan. 

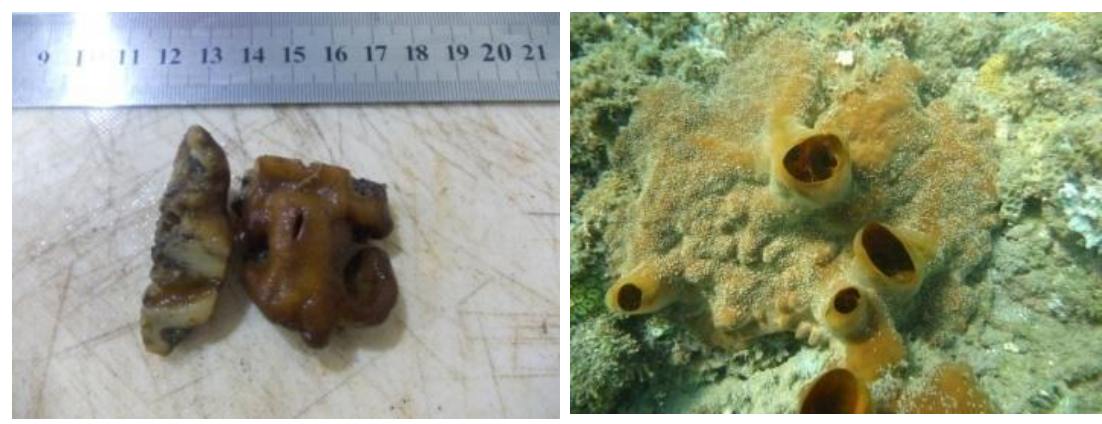

Gambar 1. Sampel C. varians

A) C. varians di Perairan

B) Sampel yang Akan Diekstrak

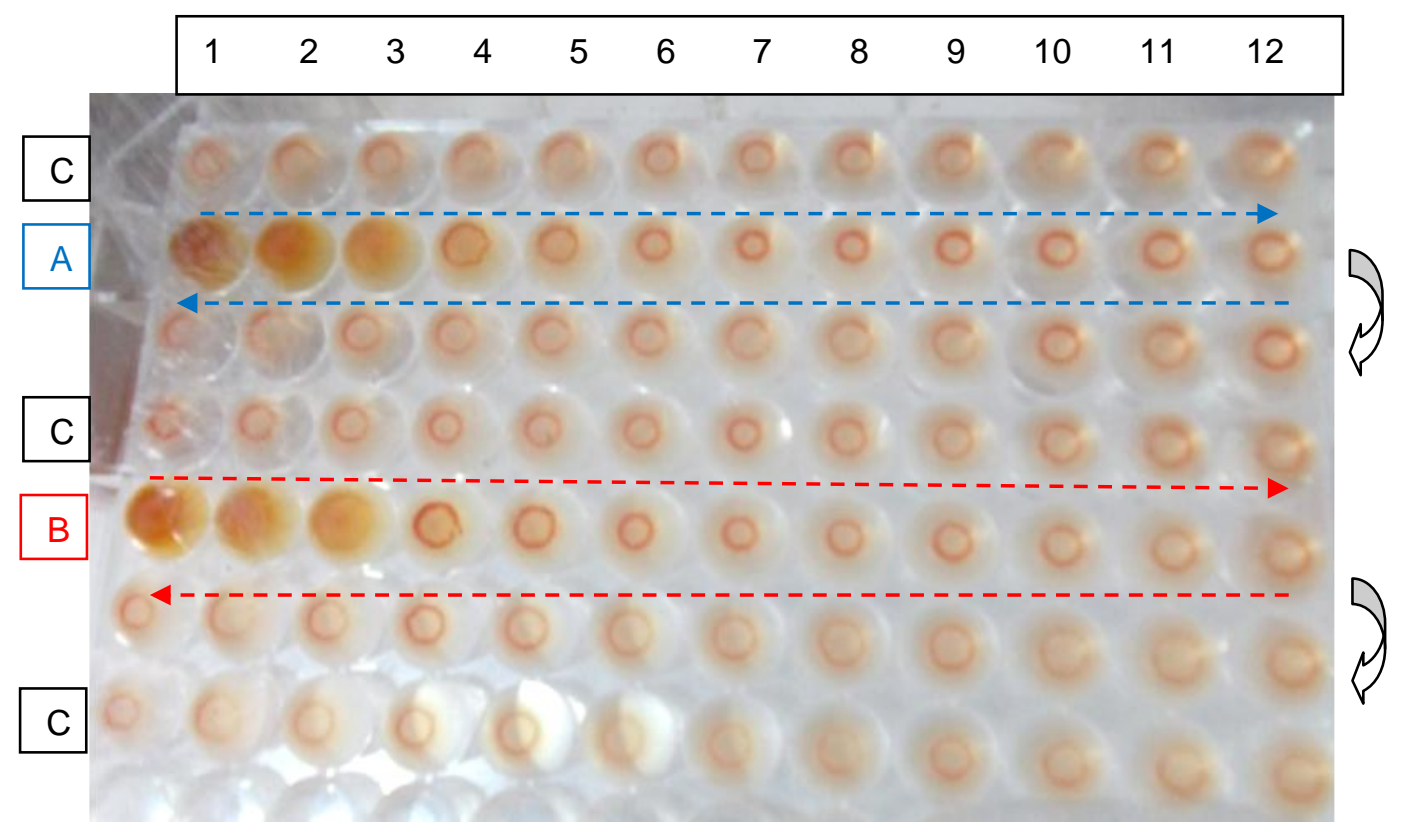

Gambar 2. Aktivitias Lektin Secara Makroskopis pada Mikrotiter Plate Keterangan : 1,2,3... : Pengenceran; $A, B, \ldots$ : Pengulangan; $C$ : Kontrol

(+) cekungan 1 sampai 4 terjadi aglutinasi

(-) cekungan 5 sampai 24 tidak terjadi aglutinasi

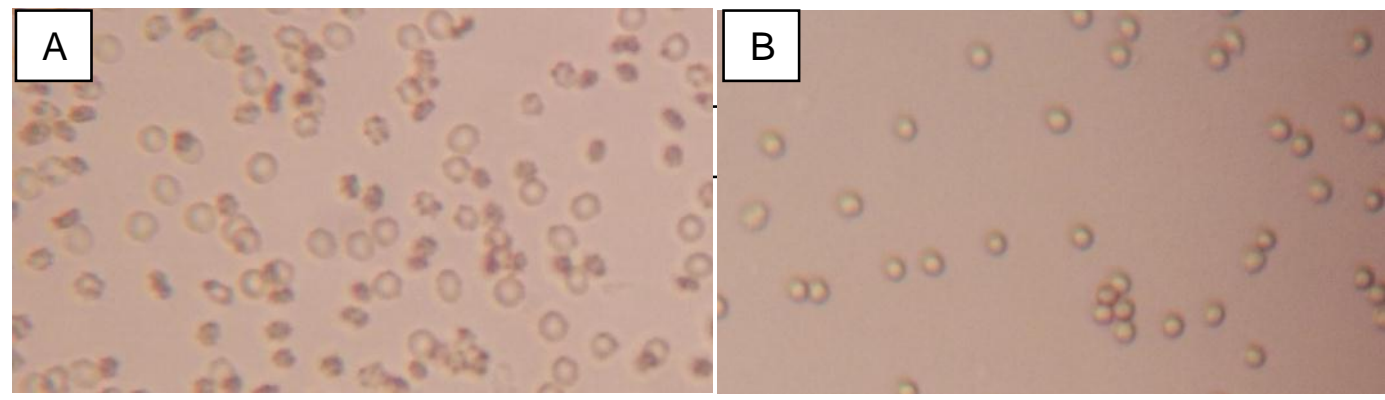

Gambar 3. Aktivitas Lektin (Secara Mikroskopis)

A) Kontrol

B) Titer Aglutinasi 


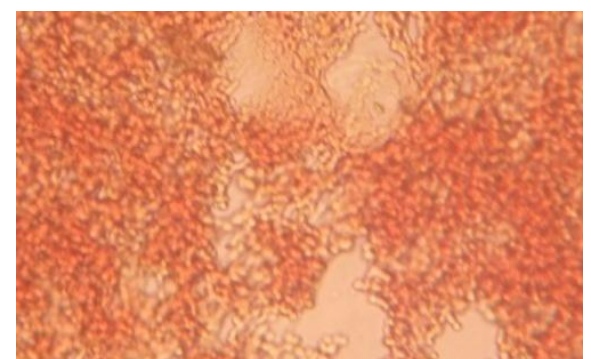

Gambar 4. Aglutinasi yang Terjadi pada

Eritrosit Manusia Golongan Darah O

Vinesian (2010) mengungkapkan bahwa protein dapat mengalami denaturasi akibat panas dan pengaruh mekanik. Namun menurut Kumajas (1994) suhu tidak terlalu mempengaruhi aktivitas lektin. Penelitian yang dilakukan untuk menyelidiki aktivitas lektin dari 5 jenis rumput laut pada suhu $25^{\circ} \mathrm{C}$ dan $4^{\circ} \mathrm{C}$ menunjukkan hasil yang tidak jauh berbeda.

Tipe sel darah juga mempengaruhi aktivitas lektin. Penelitian yang dilakukan Kumajas yang disebutkan diatas juga dilakukan pada beberapa tipe sel darah, yaitu A, $B$ dan $O$. Hasil menunjukkan bahwa golongan darah $\mathrm{O}$ menunjukkan aktivitas paling kecil. Hasil yang sama ditunjukkan oleh Moura dkk. (2006) yang meneliti aktivitas lektin pada spons $C$. varians.

Dari 3 jenis tipe darah, ditemukan bahwa golongan darah $\mathrm{O}$ menunjukkan aktivitas yang rendah. Ini dapat berarti bahwa golongan darah $\mathrm{O}$ memiliki sedikit jumlah karbohidrat sehingga aktivitas yang ditunjukkan kecil. Karena lektin mengikat karbohidrat yang ada pada permukaan sel darah. Kumajas (1994) juga dalam penelitiannya mengemukakan bahwa semakin sedikit jumlah karbohidrat semakin kecil aktivitas lektin.

\section{c. Penentuan Sisi Pengikat Gula}

Pada penentuan gula juga dilakukan pengamatan secara makroskopis dan mikroskopis. Namun tidak dapat ditentukan gula spesifik lektin dari spons ini. Titer kontrol pada penentuan gula harusnya menunjukkan aktivitas aglutinasi, namun hal tersebut tidak terlihat. Pada titer terlihat bahwa ekstrak lektin tidak mengikat sel darah (Gambar 5).

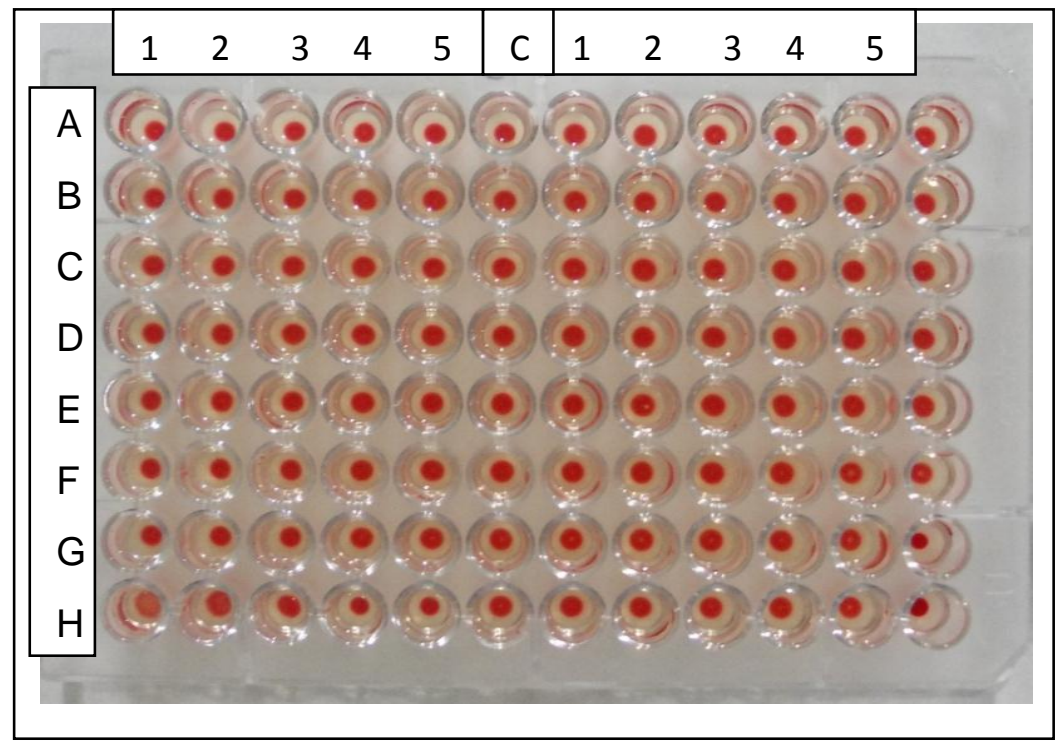

Gambar 5. Penentuan Sisi Pengikat Gula

Keterangan : $\quad$ A, B, C,... : Gula; 1, 2, 3,...: Pengenceran; C : Kontrol 


\section{KESIMPULAN}

Dari penelitian ini, dapat disimpulkan bahwa :

1. Spons C. varians mengandung aktivitas lektin yang ditunjukkan hingga pada titer ke 4, yaitu pada konsentrasi 3750 ppm.

2. Belum bisa ditentukan gula spesifik lektin dari spons $C$. varians.

\section{DAFTAR PUSTAKA}

D'Adamo, P. J. 2007. Lectins. The Individualist. 28 April 2013.

Dresch, R.R., C. B. Lerner, B. Mothes, V. M. T. Trindade, A. T. Henriques and M. M. VosáriHampe. 2012. Biological Activities of ACL-I and Physicochemical Properties of ACL-II, Lectins Isolated From the Marine Sponge Axinella corrugata. Comparative Biochemistry and Physiology Part B : Biochemistry and Molecular Biology. Vol. : 161, Issue : 4, Pages : 365-370. 1 Maret 2012.

Gilboa-Garber, N and N Garber. 1989. Microbial Lectin Cofunction with Lytic Activities as a Model for a General Basic Lectin Role. FEMS Microbiology Letters. Vol. : 63, Issue : 3, Pages : 211-221. 1 Maret 2012.

Hirabayashi, J. 1997. Introduction to "Lectin". GlycoWordindex. 22 Oktober 2012.

Kasper, M., G. Haroske, K. Pollack, A. Migheli, and M. Müller. 1993. Heterogenous Dolichos Biflorus Lectin Binding to a Subset of Rat Alveolar Macrophages in Normal and Fibrotic Lung Tissues. Acta Histochemica.
Vol. : 95, Issue : 1, Pages : 111. 1 Maret 2012.

Kim, S and P. Dewapriya. 2012. Chapter 8-Bioactive Compounds from Marine Sponges and Their Symbiotic Microbes : A Potential Sources of Nutraceuticals. Advances in Food and Nutrition Research. Vol. : 65, Pages : 137-151. 1 Maret 2012.

Kumajas, J. 1994. Isolasi Aglutinin Pada Beberapa Jenis Rumput Laut. Skripsi Fakultas Perikanan. UNSRAT. 25 hal.

Moura, R. M., A. F. S. Queiroz, J. M. S. L. L. Fook, A. S. F. Dias, N. K. V. Monteiro, J. K. C. Ribeiro, G. E. D. D. Moura, L. L. P. Macedo, E. A. Santos and M. P. Sales. 2006. CvL, a lectin from the marine sponge Cliona varians: Isolation, characterization and its effects on pathogenic bacteria and Leishmania promastigotes. Comparative Biochemistry and Physiology, Part A. No. 145, Pages : $517-$ 523. Elsevier Ltd. 5 Oktober 2012.

Ngkuno, Y. 2010. Isolasi dan Pemurnian Lektin dari Alga Gracilaria verrucosa. Tesis Pascasarjana. UNSRAT. Manado. $46 \mathrm{Hal}$.

Pajic, I., Z. Kljajic, N. Dogovic, D. Sladic, Z. Juranic and M. J. Gasic. 2002. A Novel Lectin from Sponge Haliclona cratera: Isolation, Characterization and Biological Activity. Comparative Biochemistry and Physiology part C : Toxicology and Pharmacology. Vol. : 132, Issue : 2, Pages : 213-221. 1 Maret 2012. 
Queiroz, A. F. S., R. A. Silva, R. M. Moura, J. L. Dreyfuss, E. J. Paredes-Gamero, A. C. S. Souza, I. L. S. Tersariol, E. A. Santos, H. B. Nader, G. Z. Justo and M. P. de Sales. 2009. Growth Inhibitory Activity of a Novel Lectin From Cliona varians Against k562 Human Erythroleukemia Cells. Cancer Chemoter Pharmacol. No. 63, Pages : 1023-1033. 15 April 2013.

Rawung, L. D. 2006. Penentuan Karakteristik Sisi Pengikat Gula Lektin Dari Alga Laut Eucheuma gelatinae (Esp) J. Agardh. Skripsi Fakultas Perikanan dan Ilmu Kelautan. UNSRAT. 28 Hal.

Sharon, N., and H. Lis. 2004. Review : History of Lectins : From Hemagglutinins to Biological Recognition Molecules. Glicobiology. Vol. : 14, No. 11, Pages : 53-62. Oxford University. 29 April 2013.

Swanson, M. D., H. C. Winter, I. J. Goldstein, and D. M. Markovitz. 2010. A Lectin Isolated from Bananas Is a Potent Inhibitor of HIV Replication. The Journal of Biological Chemistry. Vol. : 285, No. 12, Pages: 8646-8655. The American Society for Biochemistry and Molecular Biology, Inc. USA. 26 April 2013.

Utama, I. H. 1996. Lektin, Sifat dan Aplikasinya dalam Biologi/Biomedis. Cermin Dunia Kedokteran. Kalbe Farma Jakarta. 12 Mei 2013.

Vinesian, M. D. 2010. Denaturasi Protein. Makalah Jurusan IImu dan Teknologi Pangan Fakultas Teknologi Industri Pertanian. Universitas Sahid Jakarta.
Watanabe, Y., N. Shiina, F. Shinozaki, H. Yokoyama, J. Kominami, S. Nakamura-Tsurata, J. Hirabayashi, K. Sugahara, H. Kamiya, H. Matsubara, T. Ogawa, dan K. Muramoto. 2008. Isolation and Characterization of L-rhamnose-binding Lectin, Which Binds to Microsporidian Guglea plecoglossi, from Ayu (Plecoglossus altivelis) Eggs. Developmental \& Comparative Immunology. Elsevier. Vol. : 32 , Issue : 5, Pages : 487-499. 1 Maret 2012.

Wong, J. H. and T. B. Ng. 2005. Isolation and Characterization of a Glucose/Mannose/RhamnoseSpecific Lectin from the Knife Bean Canavalia gladiata. Archives of Biochemistry and Biophysics. Vol. : 439, Issue : 1 , Pages : 91-98. 1 Maret 2012. 